\title{
6 Pelajaran Manajemen SDM yang Perlu Diimplementasikan
}

\section{Roudhotul Munawwaroh}

\author{
Universitas Nahdlatul Ulama Sidoarjo \\ roudhotul@protonmail.com
}

Wirausaha dan Bisnis sukar tumbuh dan berkembang tanpa sumberdaya dan staf yang dapat diandalkan oleh pemilik bisnis. Manajemen sumber daya manusia (SDM) atau Human resource (HR) senantiasa menjadi salah satu bagian penting dari perjalanan menuju kesuksesan dan keberlimpahan, terlepas dari seberapa kecil bisnis. Tatkala kita masih tidak yakin harus mulai dari mana dengan membangun upaya praktik manajemen SDM, maka artikel manajemen SDM ini adalah cocok untuk kita.

Semua organisasi membutuhkan manajemen SDM yang mumpuni (Munjidah, et al., 2017). Manajemen Sumber Daya Manusia adalah tanggung jawab untuk produktivitas dan hubungan konstruktif organisasi dengan karyawannya (Purnomo, Putri, \& Rosyidah, 2017). Manajemen Sumber Daya Manusia digunakan sebagai penunjang untuk meningkatkan perekonomian (Asitah et al., 2018). 
Kajian ini telah meminta para ahli untuk memberi panduan tentang bagaimana mempertahankan praktik manajemen SDM terbaik untuk membantu mengembangkan bisnis. Berikut adalah beberapa tips dan pelajaran sumber daya manusia untuk bisnis yang perlu dipraktekkan anda dari para profesional manajemen SDM.

\section{Perluas Keahlian Anda}

Berusaha keras untuk meningkatkan keahlian Anda. Ini bisa melalui e-learning, seminar berbasis sektor, kursus pelatihan atau sekadar mengambil proyek yang melengkapi profil manajemen SDM. Ini tidak hanya akan memberikan Anda paparan vertikal yang berbeda tetapi memastikan bahwa Anda terus tumbuh. Jadwalkan lewati rapat tingkat setiap kuartal dengan manajemen puncak, ini akan membantu Anda memahami jika Anda berada di jalur yang terkait dengan visi manajemen Anda tentang organisasi dan juga profil Anda (Sondhi, 2018).

\section{Bantu Anggota Tim SDM Melihat Nilai Kontribusi Mereka}

Jika setiap anggota tim Anda tidak sepenuhnya jelas tentang apa peran mereka dan bagaimana kontribusi mereka akan berdampak pada proyek, akan sulit bagi mereka untuk tampil di 
puncaknya. Tidak cukup hanya dengan menugaskan tugas dan berasumsi bahwa mereka tahu apa yang perlu dilakukan jika mereka tidak sepenuhnya mengetahui dampaknya terhadap hasil atau proyek. Peran Anda adalah untuk memandu kemajuan melalui komunikasi dan interaksi. Seringkali orang mungkin enggan untuk berbagi ketidakpastian mereka di depan kelompok atau bahkan secara individu dengan manajer proyek karena takut terlihat tidak mampu atau tidak kompeten. Adalah tugas Anda untuk membantu anggota tim merasa bahwa mereka dapat mendatangi Anda dengan pertanyaan apa pun tanpa penilaian. Pastikan Anda mudah didekati dan tersedia saat mereka membutuhkan Anda (Alexander, 2019).

\section{Memimpin dengan Tauladan Contoh}

Anda harus bertanggung jawab pada kebijakan Anda sendiri seperti orang lain, jika tidak lebih. Memimpin dengan memberi contoh memang menantang, tentu saja, tetapi melakukan hal itu dapat memberikan templat yang dapat diikuti oleh tim Anda (dan semua karyawan lainnya). Sulit (jika bukan tidak mungkin) untuk menegakkan aturan yang Anda sendiri langgar, dan mencoba melakukannya hanya akan membuat kebencian terhadap posisi Anda. Bantulah diri Anda sendiri dan pertahankan semua orang di pihak Anda dengan 
mematuhi aturan yang sama - itu akan membuatnya lebih mudah untuk terhubung dengan karyawan ketika mereka mengalami masalah atau perlu dibawa ke kebijakan dan praktik baru (Mulholland, 2017).

\section{Perekrutan Selektif: Mempekerjakan Orang yang Tepat}

Salah satu praktik terbaik manajemen SDM adalah perekrutan selektif. Ini memungkinkan suatu organisasi untuk mendatangkan karyawan yang menambah nilai. Anda tidak bisa merekrut siapa pun; Anda ingin orang yang cocok untuk pekerjaan itu. Perusahaan melakukan yang terbaik untuk merekrut orang-orang luar biasa karena mereka memberi nilai tambah paling tinggi pada bisnis. Penelitian menunjukkan bahwa perbedaan kinerja antara pemain berkinerja rata-rata dan berkinerja tinggi dapat mencapai $400 \%$ ! Ini berlaku untuk berbagai industri dan jenis pekerjaan, termasuk peneliti, penghibur, dan atlet. Karena itu, membawa orang yang tepat adalah kunci untuk membangun keunggulan kompetitif (Vulpen, 2018). 


\section{Hemat Waktu dan Tenaga dengan RSS untuk Konten Bermanfaat}

\begin{tabular}{cccc}
\multicolumn{2}{c}{ Penggunaan umpan } & RSS untuk \\
mengumpulkan konten dari sumber & yang
\end{tabular} bermanfaat ke satu lokasi sangat berguna. Dengan begitu, alih-alih harus berselancar di sekitar blog terkemuka di niche Anda dan secara manual memilih apa yang harus dibaca, Anda bisa memuat feed Anda dan melihat ikhtisar posting teratas sumber-sumber yang telah diterbitkan. Misalnya, katakanlah Anda berlangganan 10 blog HR berbeda sehingga Anda dapat mengawasi praktik terbaik industri, dan kemudian 10 blog lainnya untuk halhal seperti peranti lunak dan rilis teknologi mendatang. Semua ini sangat penting untuk tetap relevan dan meningkatkan baik secara pribadi maupun profesional. Sayangnya, untuk membaca konten yang mereka terbitkan Anda harus membuka semua 20 blog secara manual dan menelusuri feed mereka atau Anda harus masuk ke email Anda untuk mencari email yang mereka kirim (dan, sekali lagi, membuka secara manual posting di berbagai tab). Jauh lebih efektif untuk menyelamatkan diri dari masalah dan menggunakan umpan RSS seperti Feedly untuk secara otomatis mengumpulkan konten yang mereka terbitkan, mengaturnya berdasarkan tanggal atau popularitas, dan kemudian menelusuri satu layar untuk dengan cepat 
memutuskan apa yang akan dibaca. Tidak hanya itu, tetapi Feedly juga memungkinkan Anda membaca (sebagian besar) posting tanpa meninggalkan aplikasi, sehingga Anda dapat melewati semuanya tanpa perlu menjentikkan antar situs web (Mulholland, 2017).

\section{Pengetahuan Hukum}

Manajer manajemen SDM bukanlah pengacara, mereka juga tidak perlu menjadi pengacara. Namun, pemahaman yang baik tentang hukum ketenagakerjaan dasar sangat penting untuk kesuksesan. Seperti contoh belas kasih di atas, manajer SDM sering dihadapkan pada keputusan langsung yang memiliki konsekuensi hukum. Kapan Anda bisa mengatakan tidak pada permintaan dan kapan Anda perlu terlibat dalam proses interaktif, misalnya. Atau, kapan Anda bisa memecat orang ini tetapi bukan orang itu?. Manajer SDM yang baik juga tahu kapan dia keluar dari kedalaman dan kapan saatnya memanggil pengacara hukum ketenagakerjaan (Lucas, 2019).

Itulah beberapa tips pelajaran manajemen SDM yang perlu anda implementasikan. 


\section{References}

Alexander, M. (2019). 5 HR Management Tips to

Improve Team Performance. Retrieved June 3, 2019, from

https://www.techrepublic.com/article/5-hrmanagement-tips-to-improve-teamperformance/

Asitah, N., Maula, I., Munjidah, A., Nahdiyah, K., Yuniarti, D., Sholichah, S. A., Purnomo, A., Rosyidah, E., Anam, F., Achmadi, A.K., \& Fahmi, M. (2018, May 25). Urgensi Aktualisasi Manajemen Sumber Daya Manusia untuk Resurgensi Perekonomian di Sidoarjo.

http://doi.org/10.17605/OSF.IO/TG79P

Lucas, S. (2019). 10 Skills Every HR Manager Needs to Succeed. Retrieved May 24, 2019, from

https://www.thebalancecareers.com/skills-hrmanagers-need-to-succeed-4138124

Mulholland, B. (2017). 12 HR Management Tips to Run an Effective Business (and Prevent Total Chaos). Retrieved June 2, 2019, from https://www.process.st/hr-management-tips/ 
Munjidah, A, Zannah, I.P.N., Purnomo, A., Rosyidah, E. (2017). MI Thoriqussalam Berpegang Kepada Rosul. In Wirausaha Pendidikan Indonesia (Jilid 4). Sidoarjo: Unusida Press.

Purnomo, A., Putri, R. A., \& Rosyidah, E. (2017). Kamus Manajemen Sumber Daya Manusia. Sidoarjo: UNUSIDA Press.

Sondhi, P. (2018). Be an Outstanding HR Professional with these 7 Tips. Retrieved May 25, 2019, from https://www.entrepreneur.com/article/312894

Vulpen, E. van. (2018). 7 Human Resource Best Practices (A mini-guide to HRM). Retrieved June 2, 2019, from https://www.digitalhrtech.com/humanresource-best-practices/ 